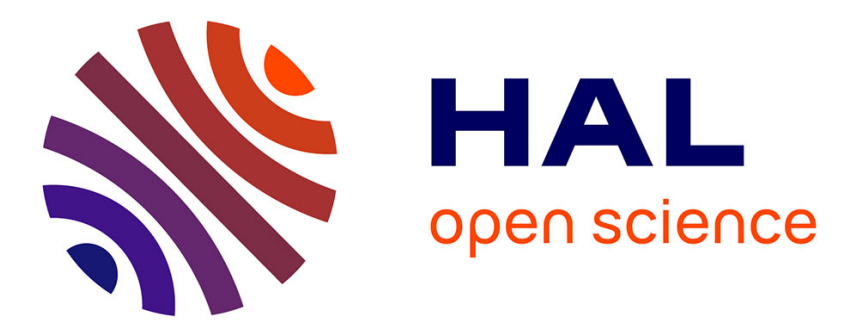

\title{
Effect of anthropogenic feeding regimes on activity rhythms of laboratory mussels exposed to natural light
}

Anthony A. Robson, Carlos Garcia de Leaniz, Rory P. Wilson, Lewis G. Halsey

\section{- To cite this version:}

Anthony A. Robson, Carlos Garcia de Leaniz, Rory P. Wilson, Lewis G. Halsey. Effect of anthropogenic feeding regimes on activity rhythms of laboratory mussels exposed to natural light. Hydrobiologia, 2010, 655, pp.197-204. 10.1007/s10750-010-0449-7 . hal-00637296

\section{HAL Id: hal-00637296 \\ https://hal.univ-brest.fr/hal-00637296}

Submitted on 31 Oct 2011

HAL is a multi-disciplinary open access archive for the deposit and dissemination of scientific research documents, whether they are published or not. The documents may come from teaching and research institutions in France or abroad, or from public or private research centers.
L'archive ouverte pluridisciplinaire HAL, est destinée au dépôt et à la diffusion de documents scientifiques de niveau recherche, publiés ou non, émanant des établissements d'enseignement et de recherche français ou étrangers, des laboratoires publics ou privés. 


\section{ISSN 0018-8158, Volume 655, Number 1}

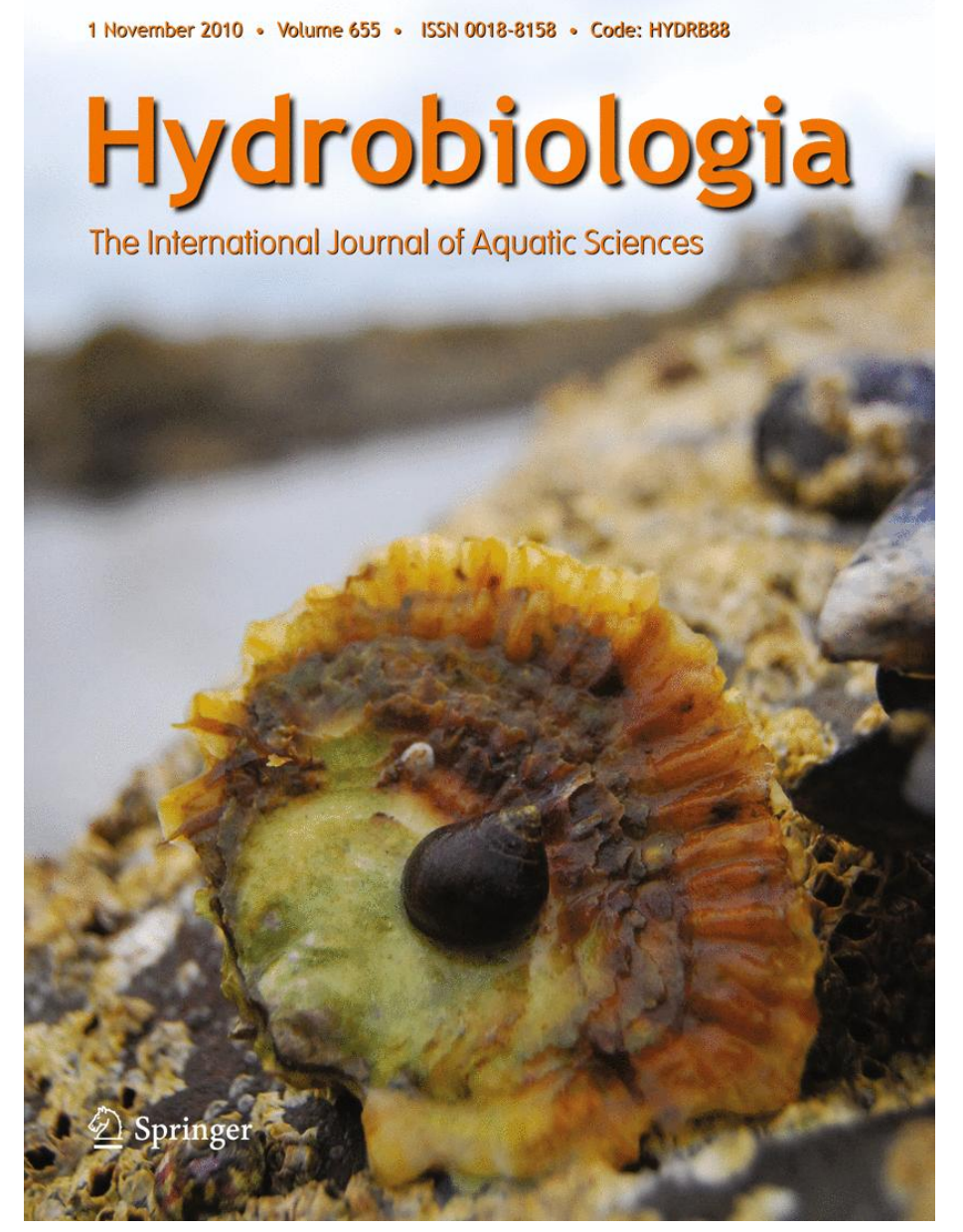

This article was published in the above mentioned Springer issue.

The material, including all portions thereof, is protected by copyright; all rights are held exclusively by Springer Science + Business Media.

The material is for personal use only;

commercial use is not permitted.

Unauthorized reproduction, transfer and/or use

may be a violation of criminal as well as civil law. 


\title{
Effect of anthropogenic feeding regimes on activity rhythms of laboratory mussels exposed to natural light
}

\author{
Anthony A. Robson - Carlos Garcia de Leaniz • \\ Rory P. Wilson • Lewis G. Halsey
}

Received: 22 February 2010/Revised: 18 August 2010/Accepted: 23 August 2010/Published online: 14 September 2010

(C) Springer Science+Business Media B.V. 2010

\begin{abstract}
Anthropogenic disturbance may affect animal behaviour and should generally be minimised. We examined how anthropogenic disturbance $(24 \mathrm{~h}$ food deprivation) affected circadian rhythms in laboratory mussels Mytilus edulis exposed to natural light in the absence of tides. Repeated measures data were collected on mussel gape angle, exhalant pumping and valve adduction using a Hall sensor system over eight consecutive $24 \mathrm{~h}$ periods when exposed to two feeding conditions after $24 \mathrm{~h}$ food deprivation. Mussels (fed once per day at either midday or midnight) exposed to natural light showed a clear day-night rhythm with increased nocturnal activity: significantly greater gape angle, increased exhalant pumping and had
\end{abstract}

Handling editor: Pierluigi Viaroli

A. A. Robson $(\square)$

Laboratoire des Sciences de L'Environnement Marin (UMR CNRS 6539), Institut Universitaire Européen de la Mer, Université de Bretagne Occidentale, Technopôle Brest Iroise, Place Nicolas Copernic, 29280 Plouzané, France

e-mail: tonesterob@hotmail.com

C. Garcia de Leaniz · R. P. Wilson

Department of Pure and Applied Ecology, Institute

of Environmental Sustainability, School of the Environment and Society, Swansea University, Singleton Park, Swansea SA2 8PP, UK

\section{G. Halsey}

School of Human and Life Sciences, Roehampton

University, Holybourne Avenue, London SW15 4JD, UK significantly higher valve adduction rates. However, circadian rhythms were less clear directly after anthropogenic food deprivation, in terms of the circadian rhythm in gape angle becoming significantly more apparent over the following days. Unlike mussels fed at midnight, those fed at midday displayed no significant change in gape angle from the hour before to the hour after they were fed, i.e. mussels given food at midday reacted to this food less than mussels fed at midnight. We suggest that independent of feeding time, laboratory mussels exposed to natural light and free from anthropogenic disturbance increase feeding activity at night because their circadian rhythms are strongly influenced by light levels. This study emphasises that the behaviour of animals in the laboratory and in the wild can be altered by anthropogenic disturbances such as vibrations caused by experimental setups and artificial illumination at night.

Keywords Anthropogenic - Circadian - Tidal . Lunar · Light - Zeitgeber - Bivalve · Behaviour . Rhythm

\section{Introduction}

Mussels are common in intertidal and shallow subtidal areas (Seed, 1976) and are ecologically important as they form large reefs that can enhance local community diversity, providing a critical link between benthic and pelagic systems by filter-feeding 
(Seed, 1976; Dame et al., 1991; Beadman et al., 2004). Mussels are robust and readily survive in basic aquariums and, as such, appear to lend themselves to laboratory-based, behavioural studies (see, e.g. Maire et al., 2007). However, despite this apparent advantage, laboratory mussels may behave in a manner different to wild conspecifics if conditions are inappropriate and so may be less useful invertebrate 'laboratory rats' than they seem (Robson, 2008). For example, Rao (1954) demonstrated bimodal lunarday rhythms of activity in wild mussels when transferred to the laboratory, but Winter (1969) concluded the modifiable rhythmic activity was caused by the artificial laboratory conditions. Winter (1973) found that laboratory mussel activity was not correlated with circadian, or tidal rhythms, which compliments the results of, e.g. Jorgensen (1960), Theede (1963), Davids (1964) and Wilson et al. (2005). However, either day-night or tidal activity rhythms have been reported in subtidal mussels in the wild (e.g. Newell et al., 2005; Wilson et al., 2005; Saurel et al., 2007) and both activity rhythms have been found simultaneously in in situ intertidal mussels during immersion (Robson, 2008).

Blue mussels Mytilus edulis have light-sensitive eyes (Morton, 2001) and thus, in the absence of tides, light intensity as a strong Zeitgeber, may have an effect (or have a greater effect) on the rhythmicity of minimally disturbed animals. Indeed, periods of light and dark have been shown to reduce and increase feeding activity and/or growth in blue mussels (Huntsman, 1921; Dodgson, 1928; Coulthard, 1929; Andreu, 1960; Seed, 1969; Strömgren, 1976a, b; Nielsen \& Strömgren, 1985; Trevelyan \& Chang, 1987). Together with reports of a significant increase in gape angle and number of shell valve adduction events in wild subtidal and intertidal mussels at night (Wilson et al., 2005; Robson, 2008, respectively), it would appear that blue mussels can exhibit higher activity levels during the hours of darkness. In contrast, the constant illumination at night of laboratory mussels may explain why Ameyaw-Akumfi \& Naylor (1987) found only a weak tendency for shellgape to be greatest during the night time. Indeed, periodic or constant illumination at night may explain why neither Newell et al. (2005) nor Saurel et al. (2007) reported greater activity at night, in in situ subtidal mussels. These results raise questions about the ecological variables that affect the activity patterns of mussels and the differences between laboratory and field results (cf. Wilson et al., 2005; Gattermann et al., 2008). Beyond this, the extent and intensity of artificial lighting at night has generally increased around the coasts of developed countries to such an extent that it might have substantial effects on the biology and ecology of species such as mussels in the wild (Longcore \& Rich, 2004; Horvath et al., 2009).

In this study, we examine the effect of anthropogenic food deprivation (food deprived for $24 \mathrm{~h}$ ) on circadian rhythms in laboratory mussels exposed to natural light (a natural Zeitgeber). Mussels were fed once per day, either at midday or at midnight and we hypothesised that mussels given food at midday would initially react less to the addition of food than those mussels fed at midnight. We also hypothesised that mussels would increase their nocturnal activity over time following anthropogenic food deprivation leading to an increasing difference in activity between night and day as time progressed. Data were collected using Hall sensor systems (Wilson et al., 2005; Robson et al., 2007; Robson et al., 2009) to record mussel gape angle, exhalant pumping and valve adduction. Gape angle was used as a proxy for feeding rate (Dolmer, 2000; Wilson et al., 2005; Saurel et al., 2007) although it sometimes corresponds to periods when the mussel foot is actively protruding from the shell. Exhalant pumping was used as a proxy for general activity (Robson et al., 2009). Finally, valve adduction rate was used as a proxy for activities associated with feeding, respiration, and metabolism (Garcia-March et al., 2008).

\section{Materials and methods}

All research detailed below was conducted in accordance with institutional, national and international guidelines relating to the use of bivalves in research.

\section{Mussel gape and pumping}

Intertidal mussels were collected from LR SS630875 Swansea Bay, Wales, UK at low tide by cutting their byssus threads and transferred to a flow-through aquarium system within $2 \mathrm{~h}$. 
Each mussel was subsequently equipped with a Hall sensor system that quantified mussel gape angle $\left(^{\circ}\right)$ with 22 bit resolution (recording gape angle at better than $0.01^{\circ}$ ) using the methods described by Robson et al. (2009). Equipped mussels were then placed in an aerated flow-through aquarium system containing edible seston-laden seawater from Swansea Bay, Wales, UK for at least a month before being used in experiments. They were subject to natural light conditions, including moonlight from windows and a constant seawater temperature of $14.0^{\circ} \mathrm{C} \pm \mathrm{SD}$ 0.4 during non-experimental and experimental periods.

Exhalant mussel pumping (from the top $10 \mathrm{~mm}$ of the inhalant siphon and whole of the exhalant siphon) was measured as described by Robson et al. (2009). The mussel and pumping sensor were suspended above the bottom of each tank (Robson et al., 2009), to ensure that the build up of biodeposits on the bottom of the tank during each experiment did not interfere with the mussel or the pumping sensor. No attempt was made to calibrate the high resolution exhalant pumping data. This was due to complications including pseudofaeces strings being eliminated in an exhalant water current out of the top of the inhalant siphon, sometimes when the exhalant siphon was closed; see Robson et al. (2009) for full details and cf. Macdonald et al. (2009). Thus, we display, but do not quantify, the relationship between valve gape and exhalant pumping.

Experiments: feeds at midday and midnight

A sampling frequency of $2 \mathrm{~Hz}$ was used to record mussel pumping and gape angle simultaneously (see Ropert-Coudert \& Wilson, 2004; Robson et al., 2009). All experiments took place within a 40-day period starting on 26th July 2007. 12 mussels, with an initial mean length of $76.1 \pm \mathrm{SD} 1.2 \mathrm{~mm}$ and mean wet weight of $45.7 \pm \mathrm{SD} 2.32 \mathrm{~g}$, were placed in separate, gently aerated tanks filled with 121 of $0.45 \mu \mathrm{m}$ filtered seawater. They were initially food deprived for $24 \mathrm{~h}$ before feeding. All 12 mussels were then fed $300 \times 10^{7}$ Thalassiosira weissflogii cells day ${ }^{-1}$ [a concentration of $\sim 250$ cells $\mu \mathrm{l}^{-1}$ at one moment in time, which has been associated with both feeding and copious pseudofaeces production (Robson et al., 2010)] at 12 pm (noon) over eight consecutive days (in a first set of experiments). The same 12 mussels were subsequently removed from experimental tanks and kept in an aerated flowthrough aquarium system containing edible sestonladen seawater from Swansea Bay, Wales, UK for 2 weeks before then being moved back to experimental tanks and food deprived for $24 \mathrm{~h}$. All mussels were then fed $300 \times 10^{7}$ Thalassiosira weissflogii cells day $^{-1}$ at midnight over eight consecutive days (in a second set of experiments). Mussels were fed in a locked laboratory, free from anthropogenic disturbance, using a remote controlled automatic feeder. Hence, the water in the aquaria was not replaced, nor were biodeposits removed. Preliminary mussel $(n=24)$ feeding experiments found cell concentrations in suspension to be minimal $23 \mathrm{~h} 50 \mathrm{~min}$ after each of eight consecutive additions of $300 \times 10^{7}$ Thalassiosira weissflogii cells day ${ }^{-1}$.

Statistical analysis

Gape data was tested for autocorrelation in Minitab 14 (Minitab Inc, State College, PA, USA) and a line delete program (LINEDEL, Jensen Software Systems, Germany) was used to systematically reduce the data set for each mussel when appropriate so that mean gape angle was calculated from non-autocorrelated data. A linear mixed model, including mussel individual as a random factor, was used to examine the difference in gape angle $\left({ }^{\circ}\right)$ between night and day (night gape minus day gape) of both midday and midnight fed mussels over time after anthropogenic food deprivation. Night was defined as 20:30-05: 59:59 and daylight was defined as 06:00:00-20:29:59. Analysis of covariance (ANCOVA) was used to compare the slopes of the two different linear regression lines. Paired $t$ tests were used to test for differences in the mean gape angle and adduction rate of mussels in a variety of paired conditions. For data analysis 'valve closure' was defined as gaping $<1^{\circ}$ (at $<1^{\circ}$ gape it is not possible to see a visible inhalant/ exhalant siphon opening within the two shell valves).

Calculation of the standard error of the estimate from a linear regression

The standard error $\left(\sigma_{0}\right)$ of an estimate made using a regression equation (SEE) can be used to calculate confidence intervals (CIs) for a regression line (see Zar, 1984, p. 273). However, in the present case, the 
inclusion of mussel individual as a random factor leads to the introduction of additional error terms in the calculation of $\sigma_{0}$ (cf. Green et al., 2001): valves sometimes remaining closed for $>1 \mathrm{~h}$ in daylight after feeding (e.g. Fig. 1). The difference in the change in gape angle from the hour before to

$\sigma_{0}=\sqrt{\left(\frac{\text { Error }_{\mathrm{I}}}{n_{1}}\right)+\left(\frac{\text { Error }_{\mathrm{I}}}{n_{2}}\right)+\left(\frac{\text { Error }_{\mathrm{S}}}{n_{3}}\right)+\left(\frac{\text { Error }_{\mathrm{S}}}{n_{4}}\right)+\left(\left(\text { SE Coef }^{2}\right) *\left(X_{\mathrm{S}}-\bar{X}\right)^{2}\right)}$

Error $_{\mathrm{I}}$ is the error associated with the variation between individual mussels. Error ${ }_{S}$ is the error associated with the scatter around the regression line. $n_{1}$ is the number of mussels used in each experiment, i.e. included in each regression $(=12)$ and $n_{4}$ is the total number of data points associated with those mussels (=96). $n_{2}$ is the number of new mussels for which an estimate of mean gape angle is calculated from the regression equation and $n_{3}$ is the number of measurements taken from those $n_{2}$ new mussels. SE Coef is the standard error of the coefficient. $X_{\mathrm{s}}$ is a predicted value of $X$ (used to predict a value of $Y$ ). $\bar{X}$ is the mean of all of the $X$ values used in the original regression. Prediction intervals (i.e. the 'worst case scenario') for the linear regression are calculated by setting both $n_{2}$ and $n_{3}$ to 1 , i.e. the estimate errors (prediction intervals) are calculated as if mean gape angle is estimated from one measurement of mean gape angle from one additional mussel (cf. Green et al., 2009).

\section{Results}

Visual inspection of the data for each mussel fed at midday indicated that the first addition of algal cells to mussels which had been food deprived for $24 \mathrm{~h}$ induced an increase in valve gape within a few minutes (mean change in the gape angle from the hour before (pre-fed) to the hour after feeding (postfed): $2.47^{\circ} \pm$ SE $0.14 ; n=12$ mussels) and a more subtle increase in exhalant pumping. These reached a maximum value in the hours of darkness after the first and subsequent algal additions at midday (e.g. Fig. 1). After the second and subsequent algal additions at midday, mussel response (both gaping and pumping) was less immediate and initially less pronounced (pooled mean change in the gape angle from the hour before to hour after feeding: $0.03^{\circ} \pm \operatorname{SE} 0.16, n=12$ mussels), with the shell the hour after feeding between the first and subsequent feeds at midday was significant $(n=12$ mussels, $t=12.01, P<0.001)$.

Gape angles and valve adduction rates of mussels fed at midday were significantly greater at night than during daylight $(n=12$ mussels, mean gape angle during the night and during the day: $4.57^{\circ} \pm$ SE 0.16 and $3.00 \pm 0.14$, respectively, $t=17.36, P<0.001$; mean valve adduction rate during the night and during the day: $4.3 \mathrm{~h}^{-1} \pm$ SE 0.4 and $1.9 \pm 0.3$, respectively, $t=6.44, P<0.001)$. The same was true of mussels fed at midnight $(n=12$ mussels, mean gape angle in night and day: $4.68^{\circ} \pm$ SE 0.15 and $2.71 \pm 0.15$, respectively, $t=31.90, P<0.001$; mean valve adduction rate in night and day: $4.6 \mathrm{~h}^{-1} \pm \mathrm{SE} \quad 0.4$ and $2.3 \pm 0.3$, respectively, $t=4.56, P=0.001)$. Circadian rhythms became significantly more apparent, in terms of the difference in gape angle between night and day, in fed mussels

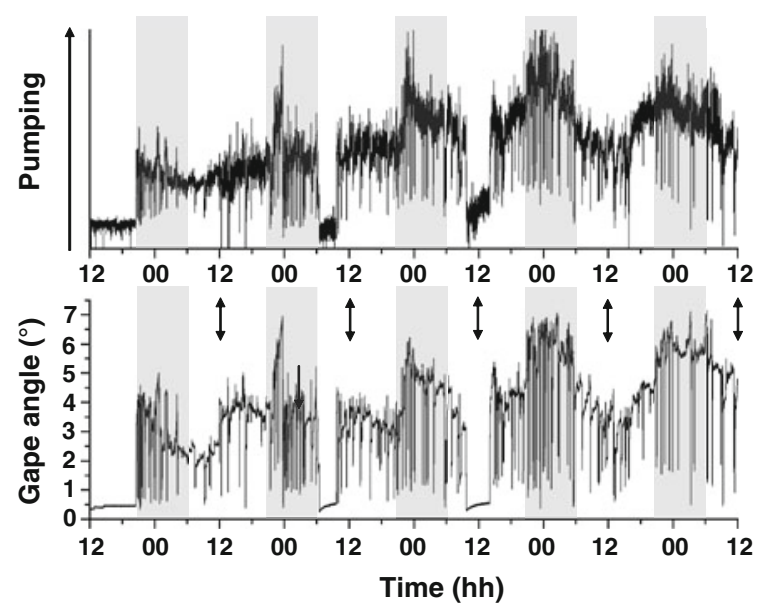

Fig. 1 Example of the gape angle and exhalant pumping of a 77-mm long blue mussel Mytilus edulis over $24 \mathrm{~h}$ food deprivation followed by four consecutive days when fed $300 \times 10^{7}$ Thalassiosira weissflogii cells day ${ }^{-1}$ at midday $(12 \mathrm{pm})$. Shaded areas indicate approximate periods of darkness. Double headed arrows indicate time fed 

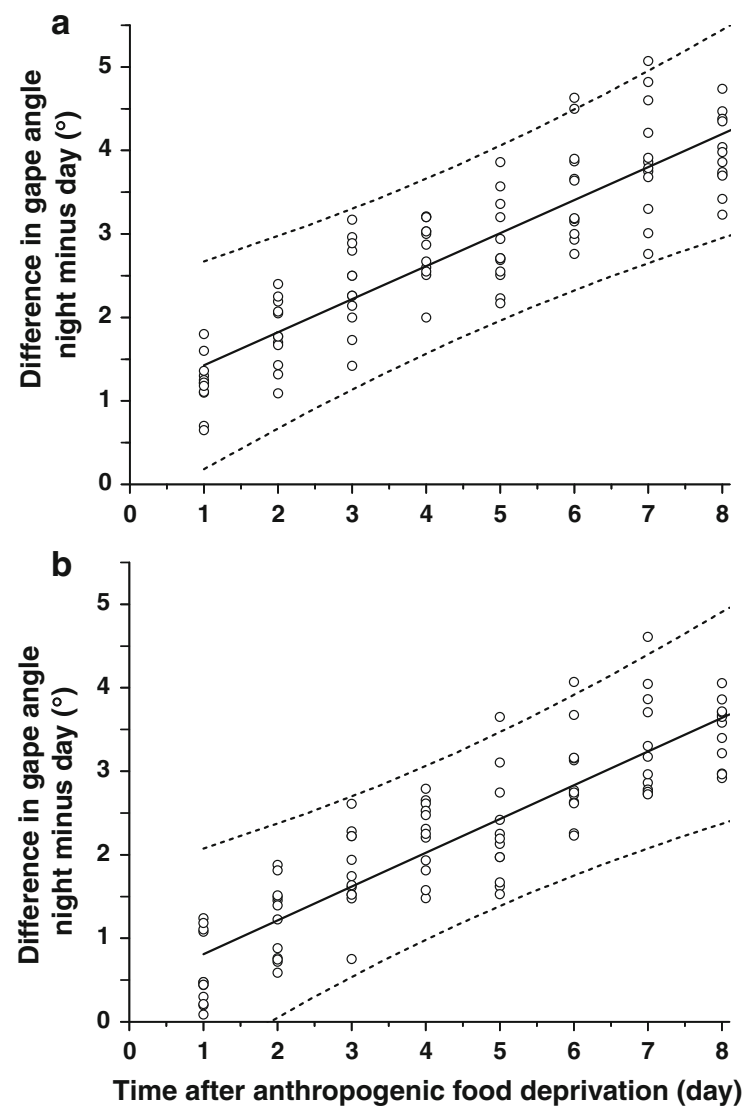

Fig. 2 The difference in gape angle between night and day (night gape minus day gape) of fed blue mussels Mytilus edulis $(n=12)$ over time after anthropogenic food deprivation a fed at midday $\left(y=0.396 x+1.030 ; R^{2}=0.85, P<0.001\right)$, b fed at midnight ( $\left.y=0.405 x+0.403 ; R^{2}=0.83, P<0.001\right)$. The best-fit regression line (solid line) and $95 \%$ prediction intervals (broken lines) are included (see 'Calculation of the standard error of the estimate from a linear regression' section)

over time after anthropogenic food deprivation (e.g. Fig. 1). This was quantified by a linear mixed model (including mussel individual as a random factor) relating the difference in mean gape between night and day over time after anthropogenic food deprivation (Fig. 2: fed midday: $F_{1,83}=415.09$, $P<0.001$, fed midnight: $F_{1,83}=371.98, \quad P<$ 0.001). The slopes of the two different (fed midday and fed midnight) linear regression lines were not significantly different $\left(F_{1}, 177=0.09, \quad P=0.758\right.$, overall slope $=0.400$ ).

Mussels fed at midnight gaped significantly less during the hours of darkness before midnight than was the case for mussels fed at midday ( $n=12$ mussels per condition, mean gape angle during the hours of

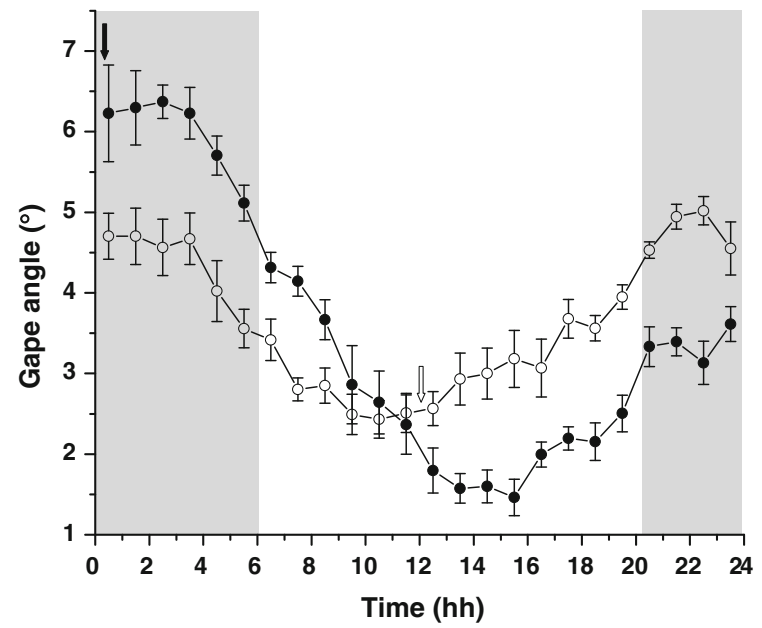

Fig. 3 Mean blue mussel Mytilus edulis gape angle over time. Mussels $(n=12)$ were fed $300 \times 10^{7}$ Thalassiosira weissflogii cells day ${ }^{-1}$ over eight consecutive days at either midday (clear arrow) or midnight (black arrow). Clear and black circles indicate mean gape \pm SE of mussels fed at midday and midnight, respectively. Shaded areas indicate approximate periods of darkness

darkness before midnight: $3.20^{\circ} \pm$ SE 0.12 and $4.60 \pm$ 0.12 , respectively, $t=29.06, P<0.001$, Fig. 3$)$. The time at which mussels were fed influenced the extent of the change in gape angle and pumping between the pre-fed and post-fed states (Fig. 3). For mussels fed at midday overall there was no significant change in the gape angle from the hour before (pre-fed) to the hour after they were fed (post-fed) $(n=12$ mussels, mean gape angle before and after feeding $2.51^{\circ} \pm$ SE 0.12 and $2.56^{\circ} \pm 0.10$, respectively, $t=0.37, P=0.72$ ). However, for mussels fed at midnight (in darkness), there was a significant increase in gape angle from the hour before to the hour after they were fed. The mean gape angle increased from $3.61^{\circ} \pm$ SE 0.11 to $6.22^{\circ} \pm 0.30 \quad(n=12$ mussels, $t=7.82, \quad P<$ 0.001 ). Mussel activity was not correlated with lunar or tidal rhythms.

\section{Discussion}

Daily activity rhythms are nearly universal among animals and their specific patterns are adaptations for appropriate habitat exploitation (for example, see Clarke, 1978; Wilson et al., 1993; Hays, 2003). Our results show that blue mussels in the laboratory exposed to natural light are significantly more active 
at night (e.g. Figs. 1, 3) and as we hypothesised their nocturnal activity increased over time after anthropogenic food deprivation (Fig. 2). This implies that both anthropogenic disturbance and light regime affect the circadian activity patterns of blue mussels (cf. Wilson et al., 2005), the latter factor from artificial lights shining on wild mussels in coastal waters at night (cf. Newell et al., 2005; Saurel et al., 2007) may well alter their natural rhythms (cf. Longcore \& Rich, 2004; Horvath et al., 2009).

In the current study, the day-night rhythm of the mussels, where greater activity is exhibited during darkness, was affected by the unnatural feeding conditions (cf. Higgins, 1980; Williams \& Pilditch, 1997). For example, mussels had low gape angles, pumping activity and valve adduction rate when they were food deprived for $24 \mathrm{~h}$, especially during daylight, and responded by increasing these measures of activity when fed (e.g. Fig. 1). After food deprivation, only after the first addition of food, was there a significant increase in the activity of the mussels when being fed at midday. This suggests that their need for nutrients at this point, at least to some degree, overrode their circadian rhythm; a demonstration of behavioural plasticity in response to a strong requirement to feed. Beyond the first day of feeding, day-fed mussels showed no significant increase in activity in the hour after the addition of food and were most active at night. Thus, as we hypothesised, mussels fed at midday generally reacted less to the addition of food compared to the significant reaction of mussels fed at midnight, indicating the strong effect of the circadian rhythm, likely influenced by light levels. Feeding mussels at midnight significantly suppressed their gape angle during the hours of darkness before midnight compared to mussels fed at midday (Fig. 3), which is likely due either to conditional learning to midnight feeding or because by the late hours of the day food in the water is negligible and thus feeding activity is not productive.

The adaptive significance of high nocturnal activity in mussels is unclear. One possibility is that such daynight gaping patterns are part of a strategy to feed while minimising the likelihood of predation by visually feeding predators (Ameyaw-Akumfi \& Naylor, 1987). For example, Oystercatchers Haematopus ostralegus, feed, in part, on gaping immersed and emersed mussels (e.g. Norton-Griffiths, 1967; Sutherland \& Ens, 1987; Goss-Custard, 1996; Stillman et al., 2000). However, some visually feeding predators such as eider ducks Somateria spp. predate on mussels regardless of whether they are gaping or not. Another, related possibility is that such day-night gaping behaviour may depend on the circadian rhythm reported for blue mussels relating to byssus thread production, where there is greater thread production during the night (Martella, 1974). From our observations, we suggest that mussels may be particularly vulnerable to predation when the foot (used as a plantar during attachment of the byssus to the substrate) is protruding from the shell because when handled, mussels adduct their valves around their foot and thus cannot fully adduct their valves.

In conclusion, our data suggest that laboratory mussels exposed to natural light, and free from anthropogenic disturbance (such as vibrations caused by experimental setups) increase their feeding activity at night, even when repeatedly fed during the day, because their circadian rhythms are strongly influenced by light levels. However, clearly light is not the only factor influencing the activity levels of mussels, which demonstrate an ability to adjust their activity patterns in response to the timing of food availability. Future work researching the natural rhythms of species should aim for the provision of natural light regimes (e.g. research on minimally disturbed animals in the wild) and for data to be obtained that allows determination of when the effects of anthropogenic factors are negligible. When working with mussels in a laboratory context, we suggest that analysis of activity rhythms should be undertaken on data collected from at least a week after anthropogenic disturbance. However, since anthropogenic illumination at night alters natural light regimes in terrestrial and aquatic ecosystems around the world (Longcore \& Rich, 2004), exposing species to natural conditions may be difficult, especially in urban areas.

Acknowledgments We are most grateful to Jonathan Green, Graeme Hays, Martin Lilley and James Wilson for help during the study. This work was funded by the European Social Fund and Deep Dock Ltd.

\section{References}

Ameyaw-Akumfi, C. \& E. Naylor, 1987. Temporal patterns of shell-gape in Mytilus Edulis. Marine Biology 95: 237-242. 
Andreu, B., 1960. Ensayos sobre el efecto de la luz en el ritmo de crecimiento mejillón (Mytilus edulis) en la Ria de Vigo. Boletin de la Real Sociedad Espanola de Historia Natural. Seccion Biologica 58: 217-236.

Beadman, H. A., M. J. Kaiser, M. Galanidi, R. Shucksmith \& R. I. Willows, 2004. Changes in species richness with stocking density of marine bivalves. Journal of Applied Ecology 41: 464-475.

Clarke, T. A., 1978. Diel feeding patterns of 16 species of mesopelagic fishes from Hawaiian waters. Fishery Bulletin 76: 495-513.

Coulthard, H. S., 1929. Growth of the sea mussel. Contributions to Canadian Biology and Fisheries 4: 123-136.

Dame, R., N. Dankers, T. Prins, H. Jongsma \& A. Smaal, 1991. The influence of mussel beds on nutrients in the Western Wadden Sea and Eastern Scheldt estuaries. Estuaries and Coasts 14: 130-138.

Davids, C., 1964. The influence of suspensions of microorganisms of different concentrations on the pumping and retention of food by the mussel Mytilus edulis L. Netherlands Journal of Sea Research 2: 233-249.

Dodgson, R. W., 1928. Report on mussel purification. Ministry of Agriculture and Fisheries, Fishery Investigations, London (Series II) 10(1): 1-498.

Dolmer, P., 2000. Feeding activity of mussels Mytilus edulis related to near-bed currents and phytoplankton biomass. Journal of Sea Research 44: 221-231.

Garcia-March, J. R., M. Sanchís Solsona \& A. M. GarcíaCarrascosa, 2008. Shell gaping behaviour of Pinna nobilis L., 1758: circadian and circalunar rhythms revealed by in situ monitoring. Marine Biology 153: 689-698.

Gattermann, R., R. E. Johnston, N. Yigit, P. Fritzsche, S. Larimer, S. Özkurt, K. Neumann, Z. Song, E. Colak \& J. Johnston, 2008. Golden hamsters are nocturnal in captivity but diurnal in nature. Biology Letters 4: 253-255.

Goss-Custard, J., 1996. The Oystercatcher: From Individuals to Populations. Oxford University Press, Oxford, UK.

Green, J. A., P. J. Butler, A. J. Woakes, I. L. Boyd \& R. L. Holder, 2001. Heart rate and rate of oxygen consumption of exercising macaroni penguins. Journal of Experimental Biology 204: 673-684.

Green, J. A., L. G. Halsey, R. P. Wilson \& P. B. Frappell, 2009. Estimating energy expenditure of animals using the accelerometry technique: activity, inactivity and comparison with the heart-rate technique. Journal of Experimental Biology 212: 471-482.

Hays, G. C., 2003. A review of the adaptive significance and ecosystem consequences of zooplankton diel vertical migrations. Hydrobiologia 503: 163-170.

Higgins, P. J., 1980. Effects of food availability on the value movements and feeding behaviour of juvenile Crassostrea virginica (Gmelin), 1. value movements and periodic activity. Journal of Experimental Marine Biology and Ecology 45: 229-244.

Horvath, G., G. Kriska, P. Malik \& B. Robertson, 2009. Polarized light pollution: a new kind of ecological photopollution. Frontiers in Ecology and the Environment 7: 317-325.

Huntsman, A. G., 1921. The effect of light on growth in the mussel. Proceedings of the Royal Society of Canada 15: 23-28.
Jorgensen, C. B., 1960. Efficiency of particle retention and rate of water transport in undisturbed lamellibranchs. ICES Journal of Marine Science 26: 94-116.

Longcore, T. \& C. Rich, 2004. Ecological light pollution. Frontiers in Ecology and the Environment 2: 191-198.

Macdonald, B. A., S. M. C. Robinson \& K. A. Barrington, 2009. Evaluating the use of exhalent siphon area in estimating feeding activity of blue mussels, Mytilus edulis. Journal of Shellfish Research 28: 289-297.

Maire, O., J. M. Amouroux, J. C. Duchene \& A. Gremare, 2007. Relationship between filtration activity and food availability in the Mediterranean mussel Mytilus galloprovincialis. Marine Biology 152: 1293-1307.

Martella, T., 1974. Some factors influencing byssus thread production in Mytilus edulis (mollusca: Bivalvia) Linnaeus, 1758. Water, Air and Soil Pollution 3: 171-177.

Morton, B., 2001. The evolution of eyes in the Bivalvia. Oceanography and Marine Biology: An Annual Review 39: 165-205.

Newell, C. R., C. H. Pilskaln, S. M. Robinson \& B. A. MacDonald, 2005. The contribution of marine snow to the particle food supply of the benthic suspension feeder Mytilus edulis. Journal of Experimental Marine Biology and Ecology 321: 109-124.

Nielsen, M. V. \& T. Strömgren, 1985. The effect of light on the shell length and defecation rate of Mytilus edulis (L). Aquaculture 47: 205-211.

Norton-Griffiths, M., 1967. Some ecological aspects of the feeding behaviour of the oystercatcher Haematopus ostralegus on the edible mussel Mytilus edulis. Ibis 109: 412-424.

Rao, K. P., 1954. Tidal rhythmicity of rate of water propulsion in Mytilus, and its modifiability by transplantation. Biological Bulletin 106: 353-359.

Robson, A. A., 2008. Gaping at Environmental Variability: How do Bivalves React to Changing Circumstance? Swansea University, UK: 248 pp.

Robson, A., R. Wilson \& C. Garcia de Leaniz, 2007. Mussels flexing their muscles: a new method for quantifying bivalve behaviour. Marine Biology 151: 1195-1204.

Robson, A. A., G. R. Thomas, C. Garcia de Leaniz \& R. P. Wilson, 2009. Valve gape and exhalant pumping in bivalves: optimization of measurement. Aquatic Biology 6: 191-200.

Robson, A. A., C. Garcia de Leaniz, R. P. Wilson \& L. G. Halsey, 2010. Behavioural adaptations of mussels to varying levels of food availability and predation risk. Journal of Molluscan Studies. doi:10.1093/mollus/eyq025.

Ropert-Coudert, Y. \& R. P. Wilson, 2004. Subjectivity in biologging science: do logged data mislead? Memoirs of National Institute of Polar Research Special Issue 58: 23-33.

Saurel, C., J. C. Gascoigne, M. R. Palmer \& M. J. Kaiser, 2007. In situ mussel feeding behavior in relation to multiple environmental factors: regulation through food concentration and tidal conditions. Limnology and Oceanography 52: 1919-1929.

Seed, R., 1969. The ecology of Mytilus edulis L. (Lamellibranchiata) on exposed rocky shores. II. Growth and mortality. Oecologia 3: 317-350. 
Seed, R., 1976. Ecology of marine mussels. In Bayne, B. L. (ed.), Marine Mussels: Their Ecology and Physiology. Cambridge University Press, Cambridge: 13-65.

Stillman, R. A., J. D. Goss-Custard, A. D. West, S. E. A. Le, V. Dit Durell, R. W. G. Caldow, S. McGrorty \& R. T. Clarke, 2000. Predicting mortality in novel environments: tests and sensitivity of a behaviour-based model. Journal of Applied Ecology 37: 564-588.

Strömgren, T., 1976a. Length growth of Mytilus edulis (Bivalvia) in relation to photoperiod, irradiance and spectral distribution of light. Sarsia 61: 31-40.

Strömgren, T., 1976b. Growth patterns of Mytilus edulis in relation to individual variation, light conditions, feeding and starvation. Sarsia 60: 25-39.

Sutherland, W. J. \& B. J. Ens, 1987. The criteria determining the selection of mussels Mytilus edulis by oystercatchers Haematopus ostralegus. Behaviour 103: 187-202.

Theede, H., 1963. Experimentelle Untersuchungen über die Filtrierleistung der Miesmuschel Mytilus edulis L. Kieler Meeresforsch 19: 20-41.

Trevelyan, G. A. \& E. S. Chang, 1987. Light-induced shell pigmentation in post-larval Mytilus edulis and its use as a biological tag. Marine Ecology Progress Series 39: 137-144.
Williams, B. G. \& C. A. Pilditch, 1997. The entrainment of persistent tidal rhythmicity in a filter-feeding bivalve using cycles of food availability. Journal of Biological Rhythms 12: 173-181.

Wilson, R. P., K. Puetz, C. A. Bost, B. M. Culik, R. Bannasch, T. Reins \& D. Adelung, 1993. Diel dive depth in penguins in relation to diel vertical migration of prey: whose dinner by candlelight? Marine Ecology Progress Series 94: 101-104.

Wilson, R., P. Reuter \& M. Wahl, 2005. Muscling in on mussels: new insights into bivalve behaviour using vertebrate remote-sensing technology. Marine Biology 147: 1165-1172.

Winter, J. E., 1969. Über den Einfluß der Nahrungskonzentration und anderer Faktoren auf Filtrierleistung und Nahrungsausnutzung der Muscheln Arctica islandica und Modiolus modiolus. Marine Biology 4: 87-135.

Winter, J. E., 1973. The filtration rate of Mytilus edulis and its dependence on algal concentration, measured by a continuous automatic recording apparatus. Marine Biology 22: $317-328$.

Zar, J. H., 1984. Biostatistical Analysis, 2nd ed. Prentice Hall, Inc, Englewood Cliffs, NJ. 